DOI 10.18699/PlantGen2019-220

\title{
Селекция интенсивных сортов гороха (Pisum sativum L.) зернового направления
}

Бабушкина Т.Д.*, Ярославцев А.А.

Научно-исследовательский институт сельского хозяйства Северного Зауральяфилиал Федерального исследовательского иентра ТюмНЦ СО РАН, пос. Московский, Тюменская область, Россия

*e-mail: babushkina_45@mail.ru

Все возрастающие требования производства к урожайности и технологичности сортов гороха предполагают создание в первую очередь интенсивных сортов. Этим требованиям отвечают созданные и зарегистрированные в последнее десятилетие сорта Русь, Кумир и Томас. Сорта короткостебельные, среднеспелые, устойчивы к полеганию и по качеству семян отнесены к ценным. Потенциальная продуктивность сортов равна 5-6 т/га. Реальная урожайность, полученная за 2010-2018 гг., при изучении в КСИ составила:3.53 т/га-у Руси, 3.96-у Кумира, 4.00у Томаса. Сорта отличаются относительно высокой стабильностью урожайности. Даже в острозасушливый 2012 г. они превышали по этому показателю стандартный сорт Ямальский на 7.3-21.0\%. Реальная урожайность сортов в производстве была близка к потенциальной. В 2010 г. в КХ «Пчела» с 20 га было намолочено по 6.0 т гороха Русь, а в КХ Шабалина за 2015-2017 гг. получено по 3.8-4.2 т/га гороха Кумир. Сорта созданы методом гибридизации. Отборы в питомниках проводились согласно выявленным закономерностям формирования урожайности сортов зернового гороха в условиях лесостепи Тюменской области. Итоги изучения 3645 селекционных линий гороха в КСИ за 2014-2018 гг. показали более тесную взаимосвязь урожайности с массой семян с одного растения $(r=0.769-0.909$ за 2014-2017 гг. при пороге 5 \% достоверности 0.294-0.320). И только в 2018 г. связь была слабая, но достоверная ( $r=0.370-0.329)$. Взаимосвязь урожайности с густотой стояния продуктивных растений была значительно слабее (от 0.167 до 0.597) и чаще недостоверной. Это связано с тем, что до конкурсного сортоиспытания «доходят» линии, устойчивые к стрессовым ситуациям резко континентального климата зоны. Густоту стояния растений в питомниках поддерживаем согласно

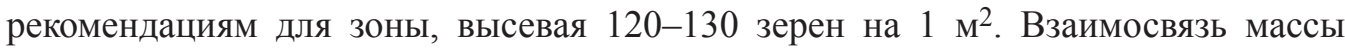
семян одного растения с элементами, ее слагающими, также не однозначна. Доказана наиболее тесная связь массы семян с количеством бобов на растении за 2015-2018 гг. ( $r=0.509-0.818)$, и только в 2014 г. связь отсутствовала. Связь с количеством зерен в бобе была значительно слабее $(r=0.063-0.519)$ и часто недостоверной. Взаимосвязь в анализируемом наборе линий гороха массы семян одного растения и урожайности с массой 1000 семян отсутствует. 